Natalia Zamkova

ORCID iD 0000-0002-3683-6454

Doctor of Philosophic Sciences, Associate Professor, Director of the Institute, Vinnytsia Institute of Trade and Economics of Kyiv National University of Trade and Economics, 87 Soborna Str., 21050 Vinnytsia, Ukraine n.1.zamkova76@gmail.com

Natalya Voinarovska ORCID iD 0000-0002-6142-3862

$\mathrm{PhD}$, Associate Professor, Associate Professor of the Department of Foreign Philology and Translation, Vinnytsia Institute of Trade and Economics of Kyiv National University of Trade and Economics, 87 Soborna Str., 21050 Vinnytsia, Ukraine natievoinarov@gmail.com

\title{
A. LUKE AND P. FREEBODY'S PEDAGOGICAL MODEL OF EDUCATING CRITICAL LITERACY OF FUTURE INTERPRETERS: APPLICATION EXPERIENCE WITHIN DOMESTIC PEDAGOGICAL PRACTICE
}

Current paper analyzes practical implications of reader roles of Luke and Freebody's Four Resources Model of critical literacy teaching in the process of training future interpreters in Ukrainian higher educational institutions. Two resources (code-breaking and meaning making) have been successfully implemented into the classic literature teaching content for Bachelor's degree students. Theoretical background, functions, and aim of these two roles have been examined. Stages of the practical classes' organization for the most fruitful students' code-breaking have been shown. Intertextual and social-cultural factors of the practical meaning-making process have been identified. Besides, the compulsory interconnection between current two resources has been proved.

Keywords: critical literacy; foreign languages competence; higher education; interpreters' training; literacy education; semantic competence; text code-breaking.

Introduction. Discussions of the literacy teaching techniques and approaches remain topical over years. The goal of the current research is to analyze two reader roles, introduced by Luke and Freebody in their Four Resources Model in literacy education of future interpreters in the Ukrainian Institutes and Universities, in particular objectives, functional applications, and their efficiency, basing on practical examples. The educationists Allan Luke and Peter Freebody designed their Four Resources Model in 1990 and later reconsidered in 1997, encouraged by the demand for enhancing social literacy level. This Model represents competencies, which a reader needs to comprehend the text successfully going from breaking the code of the abstract to making meaning of it, using the text and analyzing it. N. Melda evaluated these competencies as «necessary for being literate in a multimodal world» (Melda N., 2015, p. 3). This essay will explore two of the mentioned roles: text code-breaker and text meaning-maker. Besides, this paper will also discuss the implications of two suggested roles as appropriate to the context of the practical Foreign Language classes as part of the training process of Bachelors of Philology and Translation.

The goal of this article is to explore two of the mentioned roles: text code-breaker and text meaningmaker, and to discuss the implications of two suggested roles as appropriate for high education context, in particular for training Bachelors of Philology and Translation.

Text code-breaking. The initial stage of the Model belongs to the part of text code-breaker. This function expects reader's productive decoding the symbols in the reading, whether they are letters or figures, and associating them with verbal elements and context of usage. In fact, it means recognizing and understanding. According to G. Tompkins, R. Campbell, D. Green and C. Smith, «This role is often seen simplistically as referring only to phonics, but it also includes semantic, syntactic, pragmatic and paralinguistic knowledge» (Tompkins G., Campbell R., Green D., Smith C., 2014, p. 3). M. Strop and 
J. Carlson described the code-breaking process in action and compared it to the athletes' conduct in sport, basing on the strategy with preparation phase (identifying semiotic elements) and reproducing them in appropriate context and structure (Strop M., Carlson J., 2011, p. 133). Students can break codes within learning activity of different types: writing, reading, discussion, vocabulary comprehension and intertextual connecting, where they must explore and analyze the text, after which interpreting might follow, instructing and consulting one another about better dealing with the concrete material. Therefore, the aim of the code-breaking role is to achieve the understanding of the content that is possible only in the case of awareness of the nature of the relationship between sounds and symbols, which leads to the development of coding competence of a reader. B. Moss, D. Lapp, M. Grant and K. Johnson underline, that students' successful application of code-breaking skills proves their ability to realize the text «at a surface of basic level» (Moss B., Lapp D., Grant M., Johnson K., 2015, p. 56).

Text meaning-making. After having broken the code, students can construct the meaning, which comprises the next reader role of text meaning-maker, previously known as text participant. The current position is responsible for students' semantic competence and expects them to make conclusive meaning of the text basing on their experience and background, by actual participating in it. As it follows from the study of J. Larson and J. Marsh, «Participating in the meaning of the text inspires understanding and composing meaningful written, visual and spoken text from within the meaning system of particular culture and so forth» (Larson J., Marsh J., 2014, p. 35). The duty of the meaning-maker is to summarize the content of the text consciously, especially non-traditional reading like tables and images and define them clearly to others (Nokes J., 2013, p. 37). Evidently, the newly constructed meaning can be subjective. That is why it is important for a teacher to provide clear instructions while identifying the problem, which is possible through some supportive strategies such as guided reading, reciprocal teaching, information gap and three level guides (reading from the lines of the text, between the lines and beyond the lines). The chief goal, which meaning maker strives to achieve is to make the comprehensive interpretation of the author's information in the «multimodal text» over successful «interplay between different modalities» and comparing his experience with the notions of the passage (Ho C., Leong A., Anderson K., 2011, p. 77).

Practical application. Applying code-breaking and meaning-making roles of the Four Resources Model of Luke and Freebody provides a lot of positive experience in foreign literacy teaching practice. Firstly, let us introduce our experience of practical using codebreaking resources with Bachelors of Philology and Translation during the classic literature unit, using
Shakespeare's tragedy «Romeo and Juliet». While planning practical classes, it was crucial to formulate a question to ourselves about how we will support our students to use this role more effectively. For that reason, we demonstrated with our own examples how we start reading the book and understand it, which is essential because the chosen work is a non-traditional text with a complex plot and multiple stories. During such introduction, students were suggested to make notes for themselves. After distributing abstracts to students for familiarization, we expected their recommendations for overcoming the difficulties in the form of questions: what makes the text different from others, what parts are the most complicated, and so on (for example - (Act III) «A plague a both your houses...»).

Further, students became the instructors, preparing recommendations for others as for better text reading (ideas to agree or to disagree - for example: (Act II) «Deny thy father and refuse thy name...»). Such communicating with other members of the group in the process of code-breaking proves sociological approach to critical reading, as Larson and Marsh underlined it (Larson J., Marsh, J., 2012, p. 589), which motivates the teacher to pay more attention to the social-political aspects of work with a text. As soon as students realized their code-breaking roles, we explained what new skills and knowledge they would gain after mastering this play, such as enriching their vocabulary with plenty of new words and learning the life backgrounds of the 15th century. We strongly believe that vocabulary issues are important as far as it goes about semantics. Consequently, we worked out the original vocabulary sheets, which were available for students throughout their decoding (included examples - «strife», «wolvish-ravening», «morrow») and which predicted the usage of the most related phrases in students' performance. Confidently, such organization of our practical classes helped our students to understand the essence of code-breaking process and functions, and their own roles in it.

Complete decoding equipped students for the next step - meaning building, the subsequent stage of the critical reading model, which is potentially able to bring students closer to the highest level of text critic. Reasonably, the same group of Bachelors of Philology and Translation was participating, engaged in the additional analysis of the same Shakespeare's play, as far as they already had the required knowledge of the text genre and topic. The core question, which directed our work planning in this section, was about possible influences on «text participants» in the process of their meaning composing.

Previously, we suggested dividing students into five groups. Each group received a definite part of the play for individual reading, according to five stages of the plot development of the drama. Group 1 accepted «The Exposition», which consisted of Prologue, Act I, Scenes 1-4; Group 2 - «The Growth»: Act I, Scene 5, 
Act II, Scenes 1-6; Group III - «The Climax», Act III, Scene 1; Group IV - «The Resolution», Act III, Scenes 2-5, Act IV, Scenes 1-5, Act V, Scenes 1,2; Group $\mathrm{V}-\ll$ Conclusions», Act V, Scene 3. The first task for students was to identify the purpose of the text, which correlates with the category of genre. Here students easily underline the structure of text composing as play, and, due to the somber content, qualified it as a tragedy. This correlation is the evidence of intertextual impact on the meaning formation. It corresponds to the F.Christie and R.Misson explanation of the meaning-making phenomenon, as bringing to the content the participant's knowledge of the situation, topic, and genre of the narration (Christie F., Misson R., 1998). The next step was firm for creating the draft of the passage read before, which was followed by editing and revising the draft correspondingly to the prospective audience, and, finally, communicating the ideas to listeners. Members of the same group already have experience of relationship with one another and realize which language methods currently would be more appropriate for the most powerful meaning constructing. In such way, the situation and socialcultural factors make the influence on the process of the meaning-building.

Conclusions. This article studies reader roles of the Four Resources Model, developed by Luke and Freebody at the end of the previous century to improve the general social level of critical reading. The paper scrutinizes two initial steps of the Model, such as text code-breaking and meaning-making roles. We can define that the practical value of the essay owes to the specific examples of classroom implications of reader roles as suitable for high eduucation content.
Viewpoints of several scientists towards the first and the second resources of the Model, their functions and aims have been studied. According to them, codebreaking role contributes to the students' coding competence and releases the process of recognizing and decoding information of the text and connecting it to the associating sound and structure. Mainly helpful for the research conduct were the example of students learning activity, which initiated further possible practical approvals of code-breaking technique. As for meaning-making, it is worth underling that this role can be operated only after successful implementation of the first one. Here the dominant factor for text analyzing is the personal experience of the meaningmaker. As recent works, dedicated to the issues of critical reading, evidence, a meaning-maker, in fact, becomes the participants of the text and interprets it through his background, which leads to the development of his semantic competence.

A. Luke and P. Freebody's Model provides a lot of positive involvement thanks to applying two roles in the practical teaching activity. The environment, for realization functions and achieving goals of this approach, was chosen as the classical literature unit, using Shakespeare's tragedy «Romeo and Juliet», conducted to the Bachelors of Philology and Translation in one of the Ukrainian Institutes. The most fruitful implications of the code-breaking process include consulting each other, question building, picking up the ideas for discussion, as well as drawing attention to the specific vocabulary of the text. Benefits of meaning constructing of the text comprise students' social-cultural background for group analyzing of the separate sections of the text and communicating it to the familiar audience.

\section{References}

1. Christie F., Misson R. (1998). Literacy and Schooling. London: Routledge, 192, ISBN:9780415170178, DOI:10.4324/9780203019559 (eng).

2. Ho C. M., Leong A. P., Anderson K. T. (2011). Transforming Literacy and Language: Multimodality and Literacy in the New Media Age. Bloomsbury Academic, 244, ISBN:978-1-4411-2391-6, DOI:10.5040/9781474212014 (eng).

3. Larson J., Marsh J. (2013). The SAGE Handbook of Early Childhood Literacy. London: SAGE Publications Ltd., 704, DOI:10.4135/9781446247518 (eng).

4. Larson J., Marsh J. (2015). Making Literacy Real: Theories and Practices for Learning and Teaching. London: SAGE Publications Ltd, 190, DOI:10.4135/9781473910508 (eng).

5. Melda N. Y. (2016). Handbook of Research on Media Literacy in the Digital Age. Hershey, PA: IGI Global, 532, DOI:10.4018/978-1-4666-9667-9 (eng).

6. $\quad$ Moss B., Lapp D., Grant M., Johnson K. (2015). A close look at Close Reading: Teaching Students to Analyze Complex Texts. Alexandria, United States: Association for Supervision \& Curriculum Development, 208 (eng).

7. Nokes J.D. (2013). Building Students' Historical Literacies: Learning to Read and Reasons with Historical Texts and Evidence. New York, NY: Routledge, 220, DOI:10.7202/1029434ar (eng).

8. Strop M., Carlson J. (2010). Multimedia Texts Set: Changing the Shape of Engagement and Learning. Winnipeg, Canada: Portage \& Main Press, 177 (eng).

9. Tompkins G., Campbell R., Green D., Smith C. (2014). Literacy for the 21st Century. New York: Pearson, 504 (eng). 


\section{Література}

1. Christie F. Literacy and Schooling. London: Routledge / F. Christie, R. Misson. - 1998. - 192 p., DOI:10.4324/9780203019559.

2. Ho C. M. Transforming Literacy and Language: Multimodality and Literacy in the New Media Age/ C. M. Ho, A. P. Leong, K. T. Anderson. - Bloomsbury Academic, 2011 - 244 p., DOI:10.5040/9781474212014.

3. Larson J. The SAGE Handbook of Early Childhood Literacy / J. Larson, J. Marsh. - London: SAGE Publications Ltd. - 2013. - 704 p., DOI:10.4135/9781446247518.

4. Larson J. Making Literacy Real: Theories and Practices for Learning and Teaching / J. Larson, J. Marsh. London: SAGE Publications Ltd. - 2015. - 190 p., DOI:10.4135/9781473910508.

5. Melda N. Y. Handbook of Research on Media Literacy in the Digital Age / N. Y. Melda. - Hershey, PA: IGI Global, 2016. - 532 p., DOI:10.4018/978-1-4666-9667-9.

6. Moss B. A close look at Close Reading: Teaching Students to Analyze Complex Texts / B. Moss, D. Lapp, M. Grant, K. Johnson. - Alexandria, United States: Association for Supervision \& Curriculum Development, 2015. -208 p.

7. Nokes J. D. Building Students' Historical Literacies: Learning to Read and Reasons with Historical Texts and Evidence / J. D. Nokes. - New York, NY: Routledge, 2013. - 220 p., DOI:10.7202/1029434ar.

8. Strop M. Multimedia Texts Set: Changing the Shape of Engagement and Learning / M. Strop, J. Carlson. Winnipeg, Canada: Portage \& Main Press, 2010. - 177 p.

9. Tompkins G. Literacy for the 21st Century / G. Tompkins, R. Campbell, D. Green, C. Smith. - New York: Pearson, 2014. - 504 p.

\section{ПЕДАГОГИЧЕСКАЯ МОДЕЛЬ РАЗВИТИЯ КРИТИЧЕСКОЙ ГРАМОТНОСТИ БУДУЩИХ ПЕРЕВОДЧИКОВ А. ЛЮКА И П. ФРИБОДИ: ОПЫТ ПРИМЕНЕНИЯ В ОТЕЧЕСТВЕННОЙ ПЕДАГОГИЧЕСКОЙ ПРАКТИКЕ}

Замковая Наталия, доктор философских наук, доцент, директор института, Винницкий торгово-экономический институт Киевского национального торгово-экономического университета, ул. Соборная, 87, 21050 Винница, Украина, n.l.zamkova76@gmail.com

Войнаровская Наталья, кандидат педагогических наук, доцент, доцент кафедры иностранной филологии и перевода, Винницкий торгово-экономический институт Киевского национального торгово-экономического университета, ул.Соборная, 87, 21050 Винница, Украина, natievoinarov@gmail.com

Данная статья посвящена вопросам практического применения метода обучения критической грамотности, «Четырёхсложной модели» А. Люка и П. Фрибоди, в процессе подготовки будущих переводчиков в высших учебных заведениях Украины. Две роли данной модели (декодирование текста и формирование смысла) были успешно реализованы в русле учебного курса «Классической литературы» для соискателей степени бакалавра филологии и перевода. Изучены теоретические основы, функииональность и цели двух указанных ролей. Продемонстрированы стадии организачии практических занятий, обеспечивающие наиболее результативное декодирование текста студентами. Установлены интертекстуальные и социально-культурные факторы практического формирования смысла нового текста. Кроме того, доказана неизбежная взаимосвязь между анализируемыми двумя функииями читателя.

Ключевые слова: воспитание грамотности; высшее образование; декодирование текста; иноязычная компетенция; критическая грамотность; подготовка переводчиков; семантическая компетенция.

\section{ПЕДАГОГІЧНА МОДЕЛЬ РОЗВИТКУ КРИТИЧНОЇ ГРАМОТНОСТІ МАЙБУТНІХ ПЕРЕКЛАДАЧІВ А. ЛЮКА ТА П. ФРІБОДІ: ДОСВІД ВИКОРИСТАННЯ У ВІТЧИЗНЯНІЙ ПЕДАГОГІЧНІЙ ПРАКТИЦІ}

Замкова Наталія, доктор філософських наук, доцент, директор інституту, Вінницький торговельноекономічний інститут Київського національного торговельно-економічного університету, вул.Соборна, 87, 21050 Вінниця, Україна, n.l.zamkova76@gmail.com

Войнаровська Наталя, кандидат педагогічних наук, доцент, доцент кафедри іноземної філології та перекладу, Вінницький торговельно-економічний інститут Київського національного торговельно-економічного університету, вул.Соборна, 87, 21050 Вінниця, Україна, natievoinarov@gmail.com

Стаття присвячена моделі чотирвох функиіональних ролей читача, розробленій австралійськими педагогами А. Люком та П. Фрібоді наприкінці минулого сторіччя з метою підвищення загального рівня критичного читання у суспільстві. У нашому дослідженні розглянуто два первинних етапи зазначеної моделі, такі як декодування тесту та формування смислу. Практична щінність даного дослідження полягає у наведенні конкретних прикладів аудиторного застосування ролей читача у прочесі підготовки бакалаврів філологї та перекладу. 
Проаналізовано погляди ряду науковців стосовно першої та другої складових моделі, їх функцій та цілей. Відповідно, роль декодування тексту допомагає сформувати кодову компетениію студентів, що уможливлює процес розпізнання та декодування інформацї у тексті, та поєднання його з асоційованими звуками та структурами. Особливо корисними для проведення дослідження були приклади пізнавальної діяльності студентів, які доводили результативність використання технік декодування. Варто наголосити, що наступна роль формування смислу, може бути впроваджена лише за умови успішної реалізацї першої ролі. У даному випадку, вирішальним фактором у розгляді нового тексту є особистий досвід читача, тобто особи, яка формує смисл. Як свідчать останні дослідження питань критичного читання, особа, яка формує смисл, стає учасником змісту тесту та інтерпретує його через призму власного досвіду, що сприяє розвитку їі семантичної компетениії.

Практичне застосування у викладацькій діяльності двох досліджуваних ролей з моделі А. Люка та П. Фрібоді має ряд позитивних ознак. Було обрано сприятливе середовище для виконання функцій та досягнення цілей даного підходу, а саме - вивчення трагедії В. Шекспіра «Ромео $і$ Джульєтта» у межах навчального курсу «Класичної літератури» з програми підготовки бакалаврів філологї та перекладу. Найбільш вдалими проявами реалізащї процесу декодування тексту виявились такі види діяльності: взаємне консультування студентів, побудова запитань, підбір питань для дискусій, а також окрема увага до специфічного вокабуляру даного тесту. Здобутком реалізації функцї формування смислу стало врахування соціальнокультурного досвіду читача для спільного аналізу тексту та повідомлення інформації.

Ключові слова: виховання грамотності; вища освіта; декодування тексту; іншомовна компетенція; критична грамотність; підготовка перекладачів; семантична компетенція.

Стаття надійшла до редакції 17.01.2017

Прийнято до друку 25.05.2017

УДК $371.214 .114: 378.124 .8+004$

Оксана Синекоп

ORCID iD 0000-00016191-6264

кандидат педагогічних наук, доцент, доцент кафедри англійської мови технічного спрямування №2,

Національний технічний університет України

«Київський політехнічний інститут імені Ігоря Сікорського», пр. Перемоги, 37, кор. 7, 03056 м. Київ, Україна oksana.synekop@gmail.com

\title{
АНГЛОМОВНЕ НАВЧАННЯ МАЙБУТНІХ IT-ФАХІВЦІВ ЛІНГВОСТИЛІСТИЧНИМ ОСОБЛИВОСТЯМ ТЕКСТУ ПОЛІТИКИ ІНФОРМАЦІЙНОЇ БЕЗПЕКИ
}

\begin{abstract}
Процеси інформатизацї суспільства вимагають підготовки висококваліфікованих фахівців у галузі інформащійних технологій. Для успішного функціонування у професійно орієнтованому середовищі майбутні IT-фахівці повинні вміти створювати англомовний текст політики інформаційної безпеки. В даній статті визначено лінгвостилістичні особливості такого тексту: иілі, сфера вживання (професійно орієнтована), тема, функиія у мові (повідомлення), функціональний стиль (офіційно-діловий) та його риси (точність, логічність, стандартизованість, висока інформативність, імперативність), підстиль (адміністратиноканщелярський), жанр (політика інформачійної безпеки), форма мовлення (письмовий монолог), характер викладення інформацій (нейтральний), вид адміністративно-управлінського документу (розпорядчий), функціонально-смислове призначення (констатувальний тип, розповідь), форма реалізації (письмовий електронний / друкований), характер побудови (текст від третьої особи), характер відображення дійсності (нехудожній). Описано лексичні і граматичні характеристики тексту; представлено структуру тексту.

Ключові слова: жанр; лінгвостилістичні особливості; майбутні IT-фахівці; політика інформаційної безпеки; структура тексту; функціональний стиль.
\end{abstract}

Вступ. На сучасному ринку праці в Україні i за кордоном найбільш затребуваними є фахівці інформаційних технологій (IT), зокрема фахівців з кібербезпеки, оскільки в умо- вах тотальної інформатизації їх безпосередня професійна діяльність пов'язана із забезпеченням інформаційної безпеки людини, суспільства і держави. Відтак, підготовка висококваліфікованих IT- 